\title{
Microbiology can make a great contribution to the new direction of global politics
}

\author{
Claudia Sorlini
}

Keywords: Global politics, Climate change, Non-renewable energy sources

Our planet is currently being challenged by climate change which is causing severe consequences on the environment, economy, and social wellbeing. The main cause is the use of non-renewable energy sources, used in all anthropogenic activities. To this emergency, the problems of pollution are added. In particular, plastics that invade the planet are the most blatant phenomenon, and the nonsensical use of natural resources including water is also highly responsible. The United Nations Organization is so convinced of the need for all countries to face the transition towards a sustainable development model that it has dedicated to this aim the 2030 Agenda launched in 2015. The 2030 Agenda is articulated in the "17 Sustainable Development Goals" (https://www.un.org/sustainabledevelopment/sustainable-development-goals/). The European Parliament, with the recently approved Green Deal strategy (2020), is also showing a strong commitment in the same direction (https://ec.europa.eu/info/strategy/priorities-2019-2024/european-green-deal_en). Changing strategy is possible only under certain conditions, one of which, absolutely necessary, is represented by an extraordinary effort to support basic and applied scientific research. Unfortunately, this support is in short supply in many countries.

In this context, microbiology can make a great contribution to the new direction of global politics. The processes, of which the microorganisms are the driving force, require a lower energy input than similar processes carried out chemically. In addition, these processes take place according to natural pathways, thus producing marketable and

Correspondence: ClaudiaSorlini@fondazionecariplo.it Università degli Studi di Milano, Milan, Italy waste products that can re-enter the biogeochemical cycles (Cavicchioli et al., 2019; Timmis et al., 2019).

Currently, microorganisms are used in a large number of activities both in primary and secondary production (biocides, bioinoculants, food processing, improvement of food quality, production of bioactive molecules, bioenergy, cell factories, plant biofertilizers, etc.) and services (soil bioremediation, water purification, etc.). Research could certainly broaden the fields of microbial application and improve efficiency and product quality. For instance, it is estimated that an increase in the efficiency of symbiotic nitrogen fixation can result in savings of 1067 million dollars per year in the USA alone in the purchase of nitrogen fertilizers and a drastic reduction of greenhouse gas emissions (Seshadri et al., 2015). A similar rationale could be applied to pesticides, bioplastics, production of bioactive molecules for food, nutraceuticals, pharmaceuticals, etc.

Greater investment should also be directed to research into harmful and pathogenic microorganisms, given the importance they can assume, as in the case of the pandemic we are now experiencing dramatically. In general, however, greater attention is needed towards the world of infinitely small organisms, but which, as demonstrated, for better or worse, can be decisive in the life of humans, animals, plants, and the planet.

Collaboration between researchers is essential for understanding the complexity of natural and anthropogenic phenomena. Consequently, Annals of Microbiology has decided to be available in the open access form since 2020. The editorial board was inspired by the same motivation this journal had when it was born 80 years ago.

(c) The Author(s). 2020 Open Access This article is licensed under a Creative Commons Attribution 4.0 International License, which permits use, sharing, adaptation, distribution and reproduction in any medium or format, as long as you give appropriate credit to the original author(s) and the source, provide a link to the Creative Commons licence, and indicate if changes were made. The images or other third party material in this article are included in the article's Creative Commons licence, unless indicated otherwise in a credit line to the material. If material is not included in the article's Creative Commons licence and your intended use is not permitted by statutory regulation or exceeds the permitted use, you will need to obtain permission directly from the copyright holder. To view a copy of this licence, visit http://creativecommons.org/licenses/by/4.0/. 


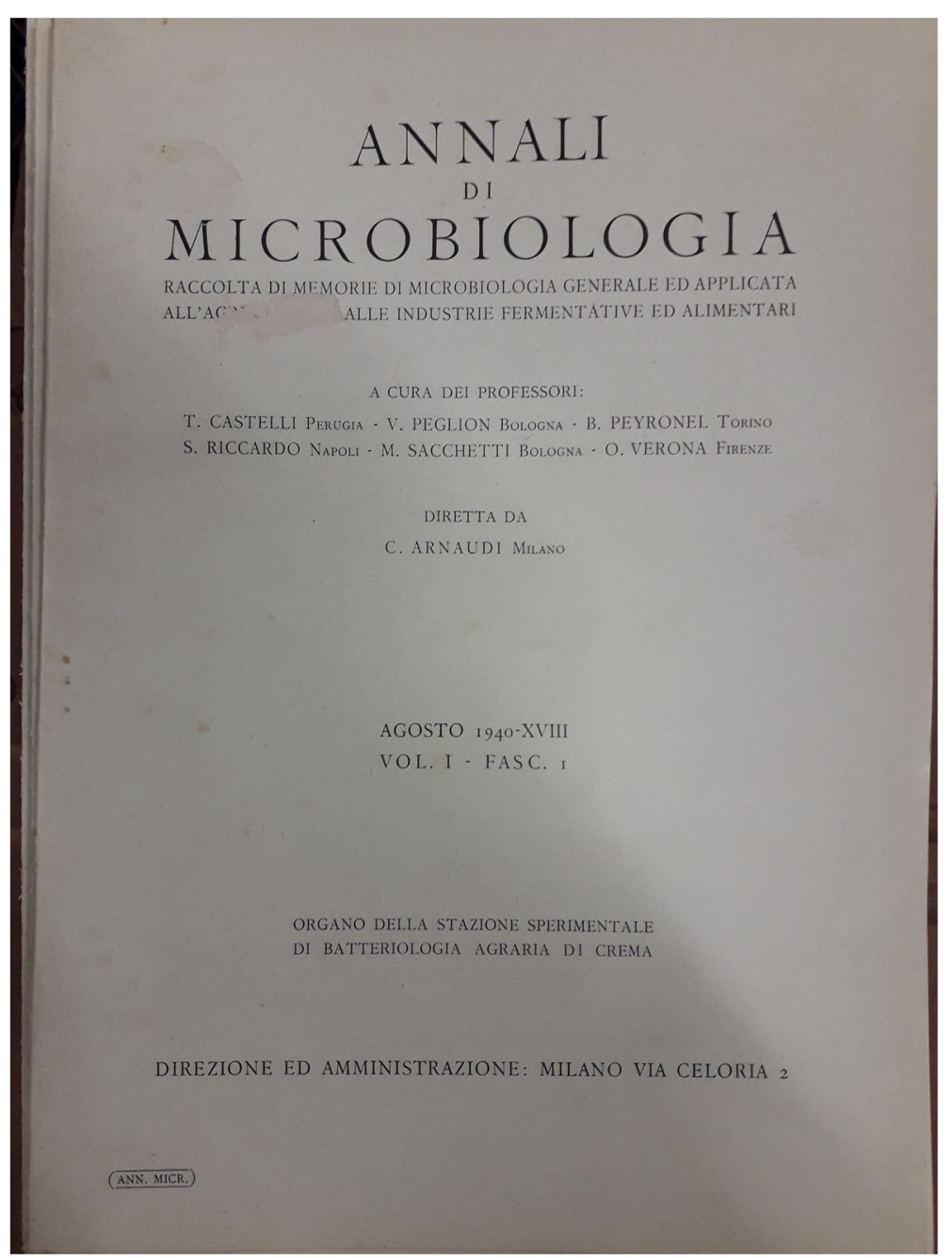

Fig. 1 The first volume of the journal

It offered a space in which researchers could make openly known their scientific acquisitions and contact each other to access information and knowledge. This function has never failed, not even in the years of the Second World War, during which the journal continued to be published.

In 1999, the journal, born in 1940 as Annali di Microbiologia (Fig. 1), took on its current name and a more marked international dimension. For 80 years, it has given thousands of researchers the opportunity to publish, thanks also to the painstaking and competent work of several thousand reviewers whose generous support never failed. Together with the current Editor-in-Chief, I would like to express my gratitude and my warmest thanks to them and to the members of the international editorial boards who have succeeded one another, with the hope that the journal will continue to satisfy the greater and greater need for excellent quality and innovation in science.

\section{Author's contributions}

The author read and approved the final manuscript.

\section{Competing interests}

The author declares that she has no competing interests.

Received: 7 November 2020 Accepted: 11 November 2020

Published online: 23 November 2020

\section{References}

Cavicchioli R, Ripple WJ, Timmis KN, Azam F, Bakken LR, Baylis M, Behrenfeld MJ, Boetius A, Boyd PW, Classen AT, Crowther TW, Danovaro R, Foreman CM, Huisman J, Hutchins DA, Jansson JK, Karl DM, Koskella B, Mark Welch DB, Martiny JBH, Moran MA, Orphan VJ, Reay DS, Remais JV, Rich VI, Singh BK, Stein LY, Stewart FJ, Sullivan MB, van Oppen MJH, Weaver SC, Webb EA, Webster NS (2019) Scientists' warning to humanity: microorganisms and climate change. Nat Rev Microbiol 17:596-586. https://doi.org/10.1038/s41579-019-0222-5

https:/ec.europa.eu/info/strategy/priorities-2019-2024/european-green-deal_en. Accessed 7 Nov 2020.

https://www.un.org/sustainabledevelopment/sustainable-development-goals/. Accessed 7 Nov 2020

Seshadri R, Reeve WG, Ardley JK, Tennessen K, Woyke T, Kyrpides NC, Ivanova NN (2015) Discovery of novel plant interaction determinants from the genomes 
of 163 root nodule bacteria. Sci Rep 5:16825. https://doi.org/10.1038/ srep 16825

Timmis K, Cavicchioli R, Garcia JL, Nogales B, Chavarría M, Stein L, McGenity

TJ, Webster N, Singh BK, Handelsman J, de Lorenzo V, Pruzzo C, Timmis

J, Ramos Martín JL, Verstraete W, Jetten M, Danchin A, Huang W, Gilbert

J, Lal R, Santos H, Yup Lee S, Sessitsch A, Bonfante P, Gram L, Lin RTP,

Ron E, Ceren Karahan Z, Roelof van der Meer J, Artunkal S, Jahn D,

Harper $L$ (2019) The urgent need for microbiology literacy in society.

Environ Microbiol 21:1513-1528. https://doi.org/10.1111/1462-2920.14611

\section{Publisher's Note}

Springer Nature remains neutral with regard to jurisdictional claims in published maps and institutional affiliations.

Ready to submit your research? Choose BMC and benefit from:

- fast, convenient online submission

- thorough peer review by experienced researchers in your field

- rapid publication on acceptance

- support for research data, including large and complex data types

- gold Open Access which fosters wider collaboration and increased citations

- maximum visibility for your research: over $100 \mathrm{M}$ website views per year

At $\mathrm{BMC}$, research is always in progress.

Learn more biomedcentral.com/submissions 